\section{New Nutrition Science project}

Madam,

The New Nutrition Science project was launched in September 2005, proposing a new conceptual framework for nutritional sciences ${ }^{(1)}$. As young public health nutritionists, we welcome this new concept and support the principles presented.

Links between the new generation of public health nutritionists and the founders of this project need to be established and reinforced in order to ensure the incorporation of these principles in upcoming projects in a sustainable way.

The New Nutrition Science project should, therefore, not only target future generations of nutritionists by encouraging a review and redevelopment of curricula, but also encourage the empowerment of the current newest generation, which we feel is an important section of the public health nutrition community.

We believe the founders of the project should involve this new generation in the fine-tuning, dissemination and consolidation of the new nutrition science in the years to come and that this involvement should be an integral part of the further development of this project.

In Europe, a network of young public health nutritionists, which includes students of the summer school 'EU Basics in Public Health Nutrition', has recently been established. We propose that this network could be a useful resource to establish and reinforce the link between the new generation of public health nutritionists and the founders of the New Nutrition Science project.

As a first step in facilitating this link, we, as members of this network, would be happy to collaborate in the organisation of a workshop or summer school that would bring together experts involved in the New Nutrition Science project and young professionals interested in learning, disseminating and integrating the new nutrition science in their future work. We believe there is much to gain in connecting the next generation of nutrition professionals with the existing leadership group in our discipline, not only to encourage mentoring, but also to ensure that the principles of the New Nutrition Science project and their application are informed by new ideas and new energy.

Vanessa Candeias Email: vanessa.candeias@gmail.com

Lena L. Nymoen Email: 1.1.nymoen@ernstud.uio.no

Emma Patterson Email: emma.patterson@prevnut.ki.se

Salome Scholtens Email: salome.scholtens@rivm.nl doi: $10.1017 / \mathrm{S} 1368980008002218$

\section{Reference}

1. Leitzmann C \& Cannon G (editors) (2005) The New Nutrition Science project. Public Health Nutr 8 , issue 6A, 667-804.

\section{Claus Leitzmann and Geoffrey Cannon, co-convenors of the New Nutrition Science project, reply}

On behalf of the New Nutrition Science project (NNSp) steering committee, now over 30 people from all major continents, Vanessa Candeias and her colleagues are right. We are delighted. We are now working with these young scientists and also with many others. We summon energy into our creaking joints, and make this short response.

The NNSp remains a joint initiative of the World Health Policy Forum and the International Union of Nutritional Sciences.

Current and projected climate and other environmental changes further emphasise the vital importance of an integrated approach to food and nutrition policy and practice. It is evident that the short era of artificially low food prices is now ending. The director-general of the International Food Policy Research Institute reported in Beijing in December 2007: 'Income growth, climate change, high energy prices, globalization, and urbanization, are transforming food consumption, production, and markets.' ${ }^{\text {(1) }}$

Since the launch of the NNSp, workshops and other meetings, some of which have included many young scientists, have been held in Spain, Canada, Morocco, China, Australia and Chile. At these meetings the principles of the NNSp have been further refined. The overall NNSp network now includes hundreds of people.

A book on the NNSp has now been commissioned and will be published by Blackwell in late 2009. Lena Nymoen and her colleagues, and other young scientists, will work with us and with senior contributors to this book. We have also promised them much more work!

$\begin{array}{r}\text { Claus Leitzmann } \\ \text { Email: claus.leitzmann@ernaehrung.uni-giessen.de }\end{array}$
Geoffrey Cannon*
Email: GeoffreyCannon@aol.com

\section{Reference}

1. von Braun J (2008) The World Food Situation: New Driving Forces and Required Actions. IFPRI's Bi-Annual Overview of the World Food Situation presented at the CGIAR Annual General Meeting, Beijing, 3 December 2007. Washington, DC: IFPRI. 